\title{
Executive Compensation Reform and the Limits of Tax Policy
}

Michael Doran

mdoran@law.georgetown.edu

This paper can be downloaded free of charge from:

https://scholarship.law.georgetown.edu/facpub/1094

http://ssrn.com/abstract=1416106

(Tax Policy Ctr. Discussion Paper No. 18, 2004)

This open-access article is brought to you by the Georgetown Law Library. Posted with permission of the author. Follow this and additional works at: https://scholarship.law.georgetown.edu/facpub

Part of the Business Organizations Law Commons, and the Tax Law Commons 


\section{Executive Compensation \\ Reform and the Limits \\ of Tax Policy \\ Michael Doran}

\section{Discussion Paper No. 18}

November 2004

Michael Doran is an Urban Institute Affiliated Scholar and was an attorney in the Office of Tax Policy at the U.S. Treasury Department from 1998 through 1999 and from 2002 through 2004. His responsibilities at Treasury included technical and policy analysis of earlier versions of the legislation discussed in this paper.

The author thanks Len Burman, Seth Green, Dan Halperin, and Paul Smith for very helpful comments on previous drafts. The views expressed are those of the author. 


\section{The Urban-Brookings Tax Policy Center}

The Tax Policy Center (TPC) aims to clarify and analyze the nation's tax policy choices by providing timely and accessible facts, analyses, and commentary to policymakers, journalists, citizens and researchers. TPC's nationally recognized experts in tax, budget and social policy carry out an integrated program of research and communication on four overarching issues: fair, simple and efficient taxation; long-term implications of tax policy choices; social policy in the tax code; and state tax issues.

Support for the Center comes from the Annie E. Casey Foundation, the Brodie Price Philanthropic Fund, the Charles Stewart Mott Foundation, the Ford Foundation, the George Gund Foundation, the Lumina Foundation, the Nathan Cummings Foundation, the Open Society Institute, the Sandler Family Supporting Foundation, and others.

Views expressed do not necessarily reflect those of the Urban Institute, the Brookings Institution, their boards of trustees, or their funders.

Publisher: The Urban Institute, 2100 M Street, N.W., Washington, DC 20037

Copyright (C) 2004 The Urban Institute

Permission is granted for reproduction of this document, with attribution to the Urban Institute. 


\section{Contents}

I. Analysis of the Deferred Compensation Legislation................................................2

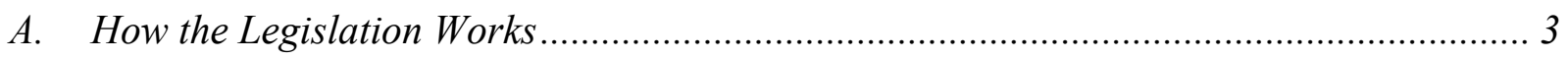

B. Accrual-Based Taxation of Managers and Substitute Taxation of Companies ................ 6

C. Effect of the Sanction Mechanism under the New Legislation ........................................ 9

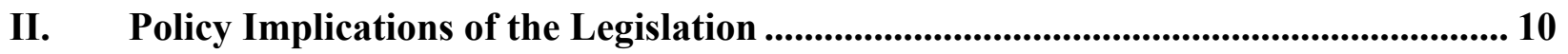

A. The Partial Change to Accrual-Based Taxation.............................................................. 10

B. The 20 Percent Surtax..................................................................................................... 13

III. A Different Approach to Deferred Compensation Reform...................................... 14 



\section{Executive Compensation Reform and the Limits of Tax Policy}

Congress recently enacted its most significant effort in decades to reform executive deferred compensation. The new legislation rewrites the tax rules for billions of dollars that corporate managers defer outside the tax-qualified pension, $401(\mathrm{k})$, and other retirement plans that cover rank-and-file employees. But the legislation misses the mark for effective reform. It does little to address the long-standing improper tax subsidy for certain deferred compensation arrangements. Compounding matters, the legislation follows previous misguided efforts to regulate corporate governance through the tax code, almost certainly leaving shareholders worse off for the effort. In short, Congress not only let slip away an opportunity for meaningful tax policy reform, but it also took a large step backward on corporate-governance policy.

Corporate scandals over the past several years apparently jarred legislators out of the complacency that had prevailed among them since 1978, when they imposed an indefinite moratorium on deferred compensation rule-making by the Treasury Department and effectively froze the law for executive pensions, long-term incentive plans, and other types of nonqualified deferred compensation. ${ }^{1}$ Suddenly aware of the aggressive arrangements that many corporations and their managers developed under the protection of the moratorium, Congress passed the new rules for deferred compensation as part of the American Jobs Creation Act of 2004 (AJCA). ${ }^{2}$

The new rules likely will trigger structural changes to most (if not all) deferred compensation arrangements in the United States. Additionally, the effective date will present very complex transition issues, potentially resulting in high adjustment costs. ${ }^{3}$ However, among the most intriguing aspects of the legislation are the tax consequences of not complying with the new rules. Those consequences can be separated into two distinct parts. First, the new legislation imposes accrual-based taxation on corporate managers whose deferred compensation arrangements fail any of the new rules. Second, it imposes a flat 20 percent surtax on managers covered by such arrangements. The legislation makes no change to the tax treatment of companies providing deferred compensation, generally allowing them to deduct currently the amounts included by the managers.

This two-part scheme represents an ineffective and misguided approach to deferred compensation reform. Rather than pursue the proper tax policy goal of strict neutrality between current and deferred compensation, the legislation attempts to discourage particular forms of deferred compensation by shifting taxation of investment earnings on the deferred compensation

\footnotetext{
${ }^{1}$ Section 132 of the Revenue Act of 1978. Nonqualified deferred compensation does not include taxqualified retirement vehicles, such as 401(k) plans.

${ }^{2}$ The new deferred compensation rules are set out in section 885 of AJCA and generally are codified at new section 409A of the Internal Revenue Code (the Code).

${ }^{3}$ The deferred compensation rules in AJCA generally apply to amounts deferred after December 31, 2004 [AJCA $\S 885(d)(1)]$. Amounts deferred before January 1, 2005, will be subject to the new rules if the plan providing for those deferrals is "materially modified" after October 3, 2004 [AJCA $\S 885(d)(2)(B)]$. Hill staff have suggested that the grandfather for amounts deferred before January 1, 2005, was intended to apply to certain of the new rules but not to others - a result plainly at odds with the statute that Congress enacted.
} 
from the company to the manager. The result is only weakly related to appropriate tax policy objectives. More important, managers in many cases are likely to reallocate the cost of accrualbased taxation back to their companies, making the after-tax costs to shareholders of providing deferred compensation no less than under prior law. Similar reallocation from managers to their companies may also occur for the 20 percent surtax, potentially resulting in higher after-tax costs to shareholders.

A better tax policy approach would have been to eliminate any preferences and dispreferences for deferred compensation by enacting straight accrual-based taxation of corporate managers. That approach would close gaps in the law that confer a tax subsidy on certain deferred compensation arrangements and would provide more straightforward and transparent results than will the new legislation. For arrangements that do not currently exploit the gaps in the law, this approach would not increase shareholder costs. Any broader reform of deferred compensation would require basic changes in corporate governance outside the tax law.

\section{Analysis of the Deferred Compensation Legislation}

A deferred compensation arrangement often constitutes little more than the contractual commitment of a company to defer payment of all or a portion of a manager's compensation to a point beyond the year the manager earns the compensation. ${ }^{4}$ Although companies and managers may use deferred compensation arrangements to finance the manager's retirement, these arrangements are distinct from tax-qualified pension and profit-sharing plans that cover rankand-file employees as well as managers. Tax-qualified plans allow the company a current deduction for pre-funding the plan, but the manager does not include the company's contributions or the earnings on those contributions until she receives distributions. By contrast, nonqualified deferred compensation arrangements defer the company's deduction until the manager includes payments in gross income. As explained below, the intended effect of this difference is to exempt investment income from tax in the case of the qualified plan but not in the case of the nonqualified plan.

Companies provide managers with deferred compensation for a number of reasons. The arrangements can be used to increase manager loyalty - for example, through clauses that impose conditional forfeitures if the manager leaves employment before a specified date or engages in post-employment competition that is harmful to the company. The value of deferred compensation may be linked to the value of company stock, which at least in theory will provide incentives for managers to increase shareholder value. Additionally, for compensation that is not performance-based, deferred compensation (unlike current compensation) generally is not subject to the \$1 million cap on the company's deduction for amounts paid to each of the top five managers. And, without question, companies use deferred compensation to facilitate managers' personal tax and estate planning.

\footnotetext{
${ }^{4}$ Nonqualified deferred compensation plans can assume several different forms. Certain arrangementscommonly known as supplemental executive retirement plans ("SERPs") — are defined benefit arrangements intended to work in tandem with qualified defined benefit plans. Other deferred compensation arrangements are modeled after 401(k) or other types of qualified defined contribution plans. These differences generally are immaterial to the tax treatment of both the company and the manager.
} 
Most tax rules for deferred compensation arrangements under prior law derive from longstanding judicial and administrative efforts to prevent abuse of the cash-basis accounting method in both compensatory and noncompensatory contexts. Thus, deferred compensation arrangements must satisfy the constructive-receipt doctrine, ${ }^{5}$ the economic-benefit doctrine, ${ }^{6}$ and the cash-equivalence doctrine. ${ }^{7}$ By contrast, the new legislation represents a direct attempt by Congress to control the taxation of nonqualified deferred compensation. Along with a broad grant of interpretive authority to the Treasury Department, ${ }^{8}$ the legislation implicitly repeals the long-standing moratorium on administrative rule-making and opens up the likelihood of further regulation of these arrangements in the near future.

\section{A. How the Legislation Works}

The legislation regulates three aspects of nonqualified deferred compensation: deferral elections, holding of assets, and distribution of benefits. Certain new rules are intended to eliminate specific abuses identified over the past several years. Other rules are intended to codify administrative positions of the government or replace amorphous judicial standards with brightline rules, thereby bringing a greater level of uniformity to the disparate contractual arrangements found in current practice.

Under the legislation, any election to defer compensation generally will have to be made no later than the taxable year before the compensation is earned (although the Treasury Department could provide for a different election-timing rule by regulation). ${ }^{9}$ A company will

\footnotetext{
${ }^{5}$ Treas. Reg. $\S 1.451-2$. The constructive-receipt doctrine generally requires a manager to include unpaid compensation in gross income unless the manager's receipt of the compensation is substantially restricted. Thus, for example, any deferred compensation that the company would pay to the manager on her request would be currently includible under the constructive-receipt doctrine.

${ }^{6}$ Sproull v. Commissioner, 16 T.C. 244 (1951), aff'd, 194 F.2d 541 (6th Cir. 1952); see also Code $\S 83$ and 402(b). The economic-benefit doctrine generally requires a manager to include any unpaid compensation that has been set aside from the company's general creditors, such as amounts that the company places in a trust for eventual payment to the manager.
}

${ }^{7}$ Cowden v. Commissioner, 289 F.2d 20 (5th Cir. 1961). The cash-equivalence doctrine generally requires a manager to include unpaid compensation if the manager can realize current value from the right to receive the payment by, for example, pledging or assigning that right.

${ }^{8}$ Code $\S 409 \mathrm{~A}(\mathrm{e})$.

${ }^{9}$ Code $\S 409 A(a)(4)(B)(i)$. The rule would allow any manager newly eligible to participate in a deferred compensation arrangement a 30-day grace period for the initial deferral election [Code $\S$ 409A(a)(4)(B)(ii)]. These rules codify the long-standing ruling position of the government. [See Rev. Proc. 71-19, 1971-1 C.B. 698.] The legislation also provides that an election to defer "performance-based compensation" earned over a period of at least one year must be made no later than six months before the end of that period [Code $\S 409 A(a)(4)(B)(i i i)]$. The Conference Committee report points out that even this six-month rule is backed up by the prior law constructive-receipt rules [H. Rep. 108-755, 108th Cong. 2d Sess. 522 (Oct. 7, 2004) (the AJCA Conference Report)]. 
not be allowed to secure its deferred compensation obligation either by holding assets offshore or by restricting creditor access to company assets if the company's financial health deteriorates. ${ }^{10}$

The new rules provide that the plan cannot pay out deferred compensation to managers earlier than separation from service, disability, death, a change of control, an unforeseeable emergency, or at a time or under a schedule prespecified under the plan. ${ }^{11}$ Any election by the manager to defer a distribution otherwise payable must be made at least 12 months in advance and in most cases must push the distribution off by at least five years. ${ }^{12}$ The plan may not accelerate the payment of deferred compensation (subject to exceptions created by the Treasury Department through regulations). ${ }^{13}$ This last provision is intended to preclude so-called "haircut" provisions that permit managers to accelerate most of their benefits if they forfeit the remainder, usually 10 percent or less of the total. The spectacle of managers drawing out almost all their deferred compensation as their companies have free-fallen into insolvency apparently became too much even for Congress, which had protected the "haircut" rule through its 1978 moratorium. $^{14}$

A deferred compensation plan that satisfies the new rules will receive the same tax treatment that prior law provides: the manager will include the deferred compensation in gross income when she receives it; ${ }^{15}$ the company will deduct the deferred compensation from gross income when the manager includes it; ${ }^{16}$ and any investment income attributable to the deferred compensation between the time of initial deferral and the time of distribution will be includible

\footnotetext{
${ }^{10}$ Code $\S 409 \mathrm{~A}(\mathrm{~b})(1)$ and (2). For reasons that defy explanation, the latter rule applies even if a change in the company's financial health does not trigger secured funding of deferred compensation but simply the placement of company assets in a rabbi trust (in which case, all the assets would be reachable by the company's business creditors) [AJCA Conference Report, 523]. Not surprisingly, the legislative history makes no attempt to justify this nonsensical result.

${ }^{11}$ Code $\S 409 A(a)(2)(A)$. Higher-level managers of public companies will have to wait six months after separation from service before receiving any distributions [Code $\S 409 \mathrm{~A}(\mathrm{a})(2)(\mathrm{B})(\mathrm{i})]$. This rule is intended to prevent managers who anticipate the insolvency of the company from leaving their positions to trigger distributions of their deferred compensation. The assumption under the legislation is that imminent failure of the company will become public information during the six-month period during which distributions are not permitted.

${ }^{12}$ Code $\S 409 \mathrm{~A}(\mathrm{a})(4)(\mathrm{C})$.

${ }^{13}$ Code $\S 409 A(a)(3)$.

${ }^{14}$ See, for example, Joint Committee on Taxation, Written Testimony of the Staff of the Joint Committee on Taxation on the Report of Investigation of Enron Corporation and Related Entities Regarding Federal Tax and Compensation Issues and Policy Recommendations 33 (JCX-10-03) (Feb. 13, 2003).

${ }^{15}$ Code $\S 451$.

${ }^{16}$ Code $\S$ 404(a)(5).
} 
in the company's gross income. ${ }^{17}$ These results follow only if the arrangement also satisfies the legal requirements imposed by prior law. ${ }^{18}$ For example, the arrangement generally must involve nothing more than the company's unfunded, unsecured promise to pay compensation in the future. ${ }^{19}$

A plan that fails the new rules will trigger accrual-based taxation for the manager. The legislation provides that the manager each year will include in gross income the full amount of her vested deferred compensation, less any amount included in a prior year, ${ }^{20}$ actual or notional investment returns on deferred amounts are treated as additional deferred compensation and therefore are taxed to the manager as they accrue. ${ }^{21}$ Additionally, the new rules impose a flat 20 percent surtax on the deferred compensation includible by the manager. ${ }^{22}$ If an arrangement initially meets the new rules but fails them later, the manager must pay an interest charge from the time of initial deferral. ${ }^{23}$ Importantly, the legislation does not change the provision that matches the company's deduction to the manager's inclusion. ${ }^{24}$ Thus, as long as the arrangement is unfunded, the company will deduct the same amount of deferred compensation included by the manager at the same time it is included by the manager (although the company will not be able to deduct the amount of the interest charge or the 20 percent surtax). ${ }^{25}$

${ }^{17}$ That result was confirmed in Albertson's Inc. v. Commissioner, 42 F.3d 537 (9th Cir. 1994), cert. denied, 516 U.S. 807 (1995), when the court denied the company a deduction for the portion of its deferred compensation obligation that represented the time value of money.

${ }^{18}$ Code $\S 409 A(c)$. In other words, the new rules do not supersede prior law; rather, they impose additional requirements that deferred compensation arrangements must satisfy.

${ }^{19}$ Rev. Rul. 60-31, 1960-1 C.B. 174.

${ }^{20}$ Code $\S 409 A(a)(1)(A)$ and (b)(3).

${ }^{21}$ Code $\S 409 A(d)(5)$. By contrast, Code section 457(f) imposes accrual-based taxation on employees of tax-exempt organizations and state and local governments for their deferred compensation but not for the earnings on their deferred compensation. In effect, the earnings are permitted to accumulate at a pre-tax rate of return, with no current taxation to either the employee or the employer.

${ }^{22}$ Code $\S 409 A(a)(1)(B)(i)(I I)$ and (b)(4)(A)(ii).

${ }^{23}$ Code $\S 409 \mathrm{~A}(\mathrm{a})(1)(\mathrm{B})(\mathrm{ii})$ and (b)(4)(B). The interest charge applies to the hypothetical tax underpayments from the failure to include the deferred compensation in income when initially deferred, rather than to the deferred compensation itself.

${ }^{24}$ AJCA Conference Report, 525.

${ }^{25}$ The Senate version of the legislation had contained additional provisions that had no analogue under the House bill. First, the Senate bill would have amended the golden-parachute rules to ensure that any deferred compensation payment made to certain managers within one year after a change of control would be subject to a 20 percent excise tax (even if it would not otherwise be treated as a golden parachute under current law). Second, the Senate bill would have prohibited any deferral of income recognition from the exercise of stock options or other equity-based compensation. Both provisions were omitted from the final legislation, although the legislative history to AJCA implies that Code section 409A effectively incorporates the second provision. See AJCA Conference Report, 524. 


\section{B. Accrual-Based Taxation of Managers and Substitute Taxation of Companies}

The significance of maintaining the rule matching the company's deduction to the manager's inclusion follows from the fact that prior law already taxes deferred compensation investment returns to the company as a substitute for accrual-based taxation of the manager. Under the pure Haig-Simons definition of income, a manager would include her vested rights to compensation as those rights accrue; this result would leave the manager indifferent, as a tax matter, between current payment and deferred payment of the compensation. Assume, for example, that a manager paying tax at the 35 percent rate is able to invest at a pre-tax rate of return of 6 percent. If the company pays the manager $\$ 100$ of current compensation in year 0 and the manager invests the after-tax proceeds, she will have $\$ 79$ after five years. ${ }^{26}$ If the company instead promises to pay the manager $\$ 100$ with interest at 6 percent at the end of five years, accrualbased taxation would still leave her with $\$ 79$ after five years. ${ }^{27}$

That generates the correct tax policy result. The law provides a tax preference for qualified plans in order to induce retirement savings, and it relies on the coverage and nondiscrimination rules to ensure that savings by high-income taxpayers result in proportional savings by low- and middle-income taxpayers. No additional tax preference is needed or appropriate to induce additional savings exclusively among high-income corporate managerswho, by law, are the only individuals eligible to participate in unfunded deferred compensation arrangements. ${ }^{28}$ Although companies may have legitimate business reasons for using deferred compensation arrangements - to increase manager loyalty or, at least in theory, to provide managers with performance-related incentives - those reasons by no means justify a federal tax subsidy. Ideally, the tax law (aside from the qualified plan regime) leaves managers indifferent between receiving current and deferred compensation for their services. ${ }^{29}$

${ }^{26}(\$ 100 \times 0.65) \times(1.039)^{5}=\$ 79$.

${ }^{27}$ Under accrual-based taxation, the manager would immediately pay $\$ 35$ tax on the $\$ 100$ of deferred compensation. During each of the five years in the deferral period, she would pay tax on the 6 percent investment earnings credited to her by the company. So, for example, in year 1 she would include $\$ 6$, giving her a tax liability of $\$ 2.10$; in year 2 , she would include $\$ 6.36$, giving her a tax liability of $\$ 2.23$; and so on. Her total tax liability, expressed in year-5 dollars (using her after-tax rate of return of 1.039 percent), would be $\$ 55$ (rounded). After the $\$ 55$ liability is applied against the year-5 distribution of $\$ 134$ $\left[=\$ 100 \times(1.06)^{5}\right]$, the manager would net $\$ 79$.

${ }^{28}$ Nonqualified deferred compensation plans are restricted to managers and highly paid employees in order to avoid the rules under the Employee Retirement Income Security Act of 1974 (ERISA) that require deferred compensation plans to be funded through a trust. Any nonqualified plan that uses a trust to satisfy ERISA would trigger current taxation for the participants under Code section 402(b); by limiting participation to what is generally known as a "top hat" group, the nonqualified plan avoids the trust requirement and, by extension, avoids triggering current taxation [ERISA § 401(a)(1)]. Additionally, a top-hat plan avoids the ERISA participation, vesting, and benefit-accrual requirements - providing the company with greater latitude in setting the terms of the plan [ERISA § 201(2)].

${ }^{29}$ Tax neutrality between current and deferred compensation would not, of course, be the correct policy result under a consumption-tax norm. 
By contrast to accrual-based taxation, our tax system allows the manager, as a cash-basis taxpayer, to defer including compensation until she receives it. Nonetheless, our system generally protects the ideal of tax neutrality between current and deferred compensation by requiring the company to pay tax on any investment income attributable to deferred compensation. Thus, if the company in the example above promises to pay the manager $\$ 100$ with interest at the end of five years, the company will pay tax on the 6 percent investment returns attributable to the $\$ 100$ during the deferral period. Assuming that the company also pays tax at the 35 percent rate, this will leave the company with an after-tax expense of $\$ 79$ after five years. ${ }^{30}$ If the manager and the company both pay tax at the same rate, this substitute taxation of the company is economically equivalent to accrual-based taxation of the manager, and both the substitute taxation of the company and accrual-based taxation of the manager are economically equivalent to a direct tax on investment income. ${ }^{31}$ As long as the manager's and the company's tax rates are the same, each of these three tax mechanisms produces the same after-tax results for the manager and the company and the same revenue for the government. ${ }^{32}$

An important corollary of the economic equivalence between accrual-based taxation of the manager and substitute taxation of the company is the general absence of any tax preference for nonqualified deferred compensation. For a qualified plan, assets are held in a tax-exempt trust and generate a pre-tax rate of return. By contrast, for a nonqualified plan, assets are held by the company and generate a post-tax rate of return. To provide the manager a pre-tax rate of return on her deferred compensation, the company must pay the manager additional compensation. Assume in the example above that the company wants to provide the manager the after-tax sum of $\$ 87$ in year 5 (this would be the after-tax amount for the manager if the company invested $\$ 100$ at a pre-tax rate of 6 percent, paid no tax on the investment income, and then distributed the accumulation of $\$ 134$ to the manager in year 5). ${ }^{33}$ The higher after-tax payout to the manager requires a higher after-tax cost for the company. Here, it would cost the company $\$ 111$, on a pretax basis, in year 0 to provide the manager with the after-tax amount of $\$ 87$ in year 5 . $^{34}$ This compares to the $\$ 100$ cost, on a pre-tax basis, in year 0 of providing the manager with the aftertax amount of $\$ 79$ in year 5 . The $\$ 11$ difference in year 0 is the additional compensation needed to provide the manager with the 6 percent pre-tax rate of return on her $\$ 100$ of deferred compensation rather than the 3.9 percent after-tax rate of return that the manager could realize on her own.

${ }^{30}\left[\$ 100 \times(1.039)^{5}\right] \times 0.65=\$ 79$.

${ }^{31}$ Daniel I. Halperin, Interest in Disguise: Taxing the "Time Value of Money”, 95 Yale L.J. 506 (1986). The term "substitute taxation" is Halperin's, as is the argument of economic equivalence among accrualbased taxation of the manager, substitute taxation of the company, and separate taxation of investment earnings. See also Noël B. Cunningham, A Theoretical Analysis of the Tax Treatment of Future Costs, 40 Tax. L. Rev. 577, 610-1 (1985).

${ }^{32}$ Halperin (1986).

${ }^{33}\left[\$ 100 \times(1.06)^{5}\right] \times 0.65=\$ 87$.

${ }^{34} \$ 111 \times(1.039)^{5}=\$ 134$. 
Because most arrangements are intended to provide a pre-tax rate of return for the manager, deferred compensation is generally more costly to the company than current compensation. All else being equal, the company should prefer to pay the manager $\$ 100$ today rather than $\$ 100$ in five years with a pre-tax rate of return. The agreement to defer payment to the manager implies an agreement by the company to increase the manager's total compensation by the difference between the pre-tax and after-tax rates of return. The "tax benefit" of deferral for the manager is funded by the company, not by the government. ${ }^{35}$ Stated differently, substitute taxation of the company should make the government indifferent, from a tax policy perspective, between current and deferred compensation.

To be sure, there are important limitations on the efficacy of substitute taxation. Most significantly, substituting taxation of the company for accrual-based taxation of the manager breaks down if the company has a lower tax rate than the manager. For this reason, a separate set of rules providing a modified form of accrual-based taxation governs nonqualified deferred compensation payable by tax-exempt organizations and state and local governments. ${ }^{36}$ However, the law does not address other differences in manager and company tax rates, such as those that result from the company's net operating losses. ${ }^{37}$ In these and similar cases, investment returns attributable to deferred compensation may be effectively exempt from taxation-meaning that substitute taxation provides no taxation at all. Those results undermine the objective of tax neutrality between current and deferred compensation, creating a de facto tax preference for deferred compensation. ${ }^{38}$ Even if one could articulate a sensible basis for subsidizing deferred

${ }^{35}$ The fact that companies are willing to increase the pay of managers by allowing them to defer portions of their compensation at a pre-tax rate of return raises questions, of course, about corporate governance. In the simplest case, one would reasonably ask why a company would allow a manager to choose between receiving her $\$ 100$ bonus currently or deferring her $\$ 100$ bonus for five years at a pre-tax rate of return that is subsidized by the company. As discussed in part II of this paper, the rent-extraction analysis developed by Lucian Bebchuk and Jesse Fried suggests that such results may be best understood by reference to fundamental agency problems in corporate governance.

${ }^{36}$ Code $\S 457(f)$. As discussed above in note 21, section 457(f) applies accrual-based taxation only to the deferred compensation, not to the investment earnings on the deferred compensation. This allows for a limited tax benefit to the employer and the employee in certain cases because the investment earnings accumulate at the employer's pre-tax rate of return. Because the investment earnings, when paid or made available to the employee, are taxed as ordinary income, the tax benefit is greatest where the underlying returns would otherwise be taxed as ordinary income (for example, includible interest). By contrast, the deferred taxation at ordinary-income rates provides a tax dispreference where the underlying returns otherwise would be taxed as capital gains.

${ }^{37}$ Even if the company pays current tax on investment earnings attributable to deferred compensation, the $\$ 1$ million cap on deductible compensation under section 162(m) may provide a tax incentive for deferred rather than current compensation. For example, if a company intends to pay a manager $\$ 2.5$ million in current compensation for a single year, the company's deduction will be limited to $\$ 1$ million unless the remaining \$1.5 million satisfies the rules for performance-based pay. Alternatively, if the company pays the manager \$1 million currently and defers the remaining \$1.5 million until after she leaves the company's employment, the company will be able to deduct the deferred amount upon payment to the manager without regard to the rules for performance-based pay.

${ }^{38}$ See Daniel Halperin, "A Fairer and More Effective Approach to Deferred Compensation," 103 Tax Notes 1187 (May 31, 2004). As Halperin notes, there is the possibility of a second tax benefit to the 
compensation - and it is difficult to imagine what such a basis might be-reserving the subsidy only for those cases where the company's tax rate is lower than the manager's defies justification. The tax preference is accidental and irrational; genuine reform would correct that result.

\section{Effect of the Sanction Mechanism under the New Legislation}

Against that analytical background, the sanction mechanism of the new legislation appears truly puzzling. The legislation effectively separates all nonqualified deferred compensation plans into "good" plans - those that satisfy the new deferral, holding, and distribution rules - and "bad" plans - those that fail to satisfy the new deferral, holding, and distribution rules. For good deferred compensation plans, the legislation preserves substitute taxation of the company as provided under prior law. This means that investment income attributable to deferred compensation will continue to be taxed to the company. For bad plans, the sanction mechanism imposes accrual-based taxation on the manager. However, the company will have matching deductions, which eliminates the substitute taxation of investment earnings provided under prior law. ${ }^{39}$ Thus, this part of the legislation generally leaves the manager and the company, considered together, with equivalent after-tax results under both good and bad deferred compensation plans. Ignoring, for now, the 20 percent surtax and any difference in the tax rates of the company and the manager, the substitute taxation of the company in the case of a good deferred compensation plan and the accrual-based taxation of the manager in the case of a bad deferred compensation plan produce the same total tax liability for the company and the manager. The difference between the two will be whether the company or the manager nominally pays tax on investment earnings during the deferral period.

The results, then, of the partial change to accrual-based taxation are as follows. For good deferred compensation plans, the tax law will be no closer to or further from the ideal of tax neutrality than prior law. The law will continue to rely on substitute taxation of the company rather than accrual-based taxation of the manager; a difference in tax rates for the company and the manager will continue to confer a de facto tax preference on certain arrangements. For bad deferred compensation plans, the law will move closer to the ideal of tax neutrality by eliminating any preference resulting from a difference in the manager's and the company's tax rates. But for plans that do not currently exploit any difference between the company's and the manager's tax rates, the two-track system of substitute taxation for good plans and accrual-based taxation for bad plans will not in itself change the tax cost of providing deferred compensation. ${ }^{40}$

manager attributable to any difference in the manager's own tax rates at the time the deferred compensation is earned and the time the deferred compensation is paid.

${ }^{39}$ Continuing with the example from note 27 , the accrual-based taxation of the manager would result in the company deducting in year 0 the $\$ 100$ of deferred compensation included by the manager in year 0 . During each of the five years in the deferral period, the company would deduct the 6 percent investment earnings included by the manager. So, for example, in year 1 the company would deduct $\$ 6$; in year 2 , it would deduct $\$ 6.36$; and so on through year 5. The total tax value of these deductions, expressed in year5 dollars (using the company's after-tax rate of return of 1.039 percent), would be $\$ 55$ (rounded). After the $\$ 55$ is applied against the year-5 distribution of $\$ 134\left[=\$ 100 \times(1.06)^{5}\right]$, the company would have a net after-tax cost of $\$ 79$.

${ }^{40}$ Again, this ignores for now the effect of the 20 percent surtax. 
The apparent premise of the legislation is that, notwithstanding the economic equivalence of accrual-based taxation and substitute taxation, managers will not be indifferent between good and bad deferred compensation because of the 20 percent surtax on bad deferred compensation. ${ }^{41}$ As argued in the next part of this paper, however, that assumes that managers themselves will bear the risk of the 20 percent surtax and that they will not reallocate that risk to their companies - which in turn assumes that managers bargain with their companies on an arm'slength basis. In other words, the 20 percent surtax effectively curbs bad deferred compensation arrangements only if one can credibly assume away the corporate governance problems that prompted Congress to enact the 20 percent surtax in the first place. As argued below, that reasoning provides a doubtful basis for responsible deferred compensation reform.

\section{Policy Implications of the Legislation}

The bifurcation of deferred compensation into good plans and bad plans raises questions as to the underlying tax or corporate-governance policy objectives of the legislation and whether the legislation is appropriately designed for those objectives. Close examination of these points suggests that the sanction mechanism is difficult to justify as a matter of tax policy. On the corporate governance side, it may have little beneficial effect and, in fact, may ultimately harm shareholders by increasing the cost of compensating managers. Section A considers the policy implications of the partial change to accrual-based taxation; section B considers the policy implications of the 20 percent surtax.

\section{A. The Partial Change to Accrual-Based Taxation}

There are several possible tax policy objectives that Congress might try to achieve through deferred compensation reform, but the new legislation seems very unlikely to achieve any of them. The most worthy tax policy objective, but in some ways the least plausible here, would be simply to ensure the appropriate taxation of deferred compensation in all cases. As indicated above, substitute taxation of the company fails to provide the correct result whenever the manager's tax rate exceeds the company's tax rate; accrual-based taxation of the manager would fill that gap. However, the division between good and bad deferred compensation plans under the legislation does not in any manner depend on the existence of any spread in tax rates for the manager and the company, so any net movement toward the ideal of tax neutrality between current and deferred compensation is more by accident than design. Additionally, the added complexity of having two distinct regimes for taxing deferred compensation makes the halting step toward tax neutrality harder to justify.

A second possible tax policy objective of the legislation would be the protection of the qualified plan system. The leverage provided by the coverage and nondiscrimination rules for qualified plans ordinarily can result in adequate retirement savings for lower- and middle-income

\footnotetext{
${ }^{41}$ Presumably, companies also might prefer good deferred compensation to bad deferred compensation because of reputational costs associated with having bad deferred compensation or because of high adjustment costs that they might incur when changing from substitute taxation to accrual-based taxation where there is an unanticipated failure to satisfy the new rules after substantial amounts have already been deferred.
} 
taxpayers only if higher-income taxpayers participate in the plans, and there is some risk that a company's nonqualified plan providing a manager with significant deferred compensation will reduce the manager's incentive to participate in the company's qualified plan. Limiting such competition between nonqualified and qualified plans is appropriate to ensure the proper functioning of the qualified plan system. ${ }^{42}$

It seems doubtful, however, that Congress seriously intended the legislation to buttress qualified plans. The legislation - as did prior law-allows essentially unlimited amounts of compensation to be deferred under a nonqualified plan; it simply shifts taxation of investment earnings from the company to the manager in the case of a bad deferred compensation plan. Surely the mere fact of a manager's ability to defer tens or even hundreds of millions of dollars under a nonqualified plan presents a challenge to qualified plans regardless of whether the plan has features such as "haircut" distributions before retirement. The allowance of unlimited deferrals undermines any objective of protecting qualified plans from competition.

A more plausible tax policy objective would be to strengthen the rules that govern the timing of the manager's inclusion in gross income. In particular, the Treasury Department has noted the government's difficulty in trying to enforce the constructive-receipt rules against taxpayers. ${ }^{43}$ The federal courts generally side with taxpayers in constructive-receipt litigation and thus encourage increasingly aggressive arrangements. Consistent with this tax policy objective, the rules under the new legislation concerning initial deferrals and distributions set bright-line parameters for how much control managers can exercise in determining when they will pay tax on their compensation. But this objective-which could have been achieved by repealing the 1978 moratorium - fails to provide any rationale for imposing substitute taxation on the company in the case of good deferred compensation plans and accrual-based taxation on the manager in the case of bad deferred compensation plans. The two approaches generally produce the same after-tax results for the taxpayers and the government. Therefore, it remains unclear how much the sanction of imposing accrual-based taxation on the manager will strengthen the enforcement position of the government. ${ }^{44}$

The fact that, even before the new legislation, providing deferred compensation with a pre-tax rate of return has been more costly to a company than providing current compensation suggests that Congress may view the legislation as promoting important objectives that have more to do with corporate governance than with tax policy. Recent work suggests that managers may prefer deferred compensation to current compensation in part because it helps "camouflage"

\footnotetext{
${ }^{42}$ Testimony of Pamela F. Olson, Assistant Secretary of the Treasury (Tax Policy) for the Committee on Finance, United States Senate, p. 2 (Apr. 8, 2003).

${ }^{43}$ Olson (2003), 4.

${ }^{44}$ Perhaps a better explanation for the tax policy objectives underlying the legislation is the notion that lawmakers, responding to public outrage over recent corporate scandals, are engaged in symbolic or expressive legislation that is intended less to have meaningful practical effects and more to assure constituents that lawmakers have done something to address the issue of managerial compensation. See Michael S. Kirsch, Alternative Sanctions and the Federal Tax Law: Symbols, Shaming, and Social Norm Management as a Substitute for Effective Tax Policy, 89 Iowa L. Rev. 863 (2004).
} 
their actual levels of pay. ${ }^{45}$ Shareholders generally do not know or understand the cost or the inefficiency of deferred compensation arrangements. ${ }^{46}$ To the extent that managers exploit this informational asymmetry to increase their pay above what they could otherwise receive through arm's-length bargaining, the use of deferred compensation rather than current compensation harms shareholders. Following that analysis, one might argue that the new legislation will protect shareholders if it makes deferred compensation inherently less attractive to managers by shifting to the managers the taxation of investment earnings.

Even if Congress is not trying to discourage deferred compensation generally, the legislation could be seen as protecting shareholders to the extent the new limitations on deferrals, holding of assets, and distributions expose managers to higher levels of risk. The law effectively requires shareholders to pay managers a premium when the manager's compensation is deferred at a pre-tax rate of return; in exchange, the manager is supposed to take on the risk that the compensation will never be paid if the company becomes insolvent. But judicial relaxation of the constructive-receipt doctrine and the legislative moratorium on administrative rule-making have allowed managers to increase their control over deferred compensation and, correspondingly, have diminished their risk of loss if the company becomes insolvent. This sharply reduces the downside to the manager's personal wealth in the event the company fails. To the extent that the legislation curtails the manager's ability to manipulate the timing of payouts and thereby increases her risk of nonpayment if the company fails, her personal incentives should be better aligned with the interests of the shareholders.

The difficulty here is that the sanction mechanism in the legislation is a poor instrument for achieving these corporate-governance objectives. If one could expect that shifting tax from the company (in the case of good deferred compensation) to the manager (in the case of bad deferred compensation) would have any real economic effect, one could argue that the sanction in the legislation might lead the manager to bargain with the company only for good deferred compensation. That result would fulfill the shareholder-protection aims of the legislation. But accrual-based taxation of the manager and substitute taxation of the company provide equivalent after-tax outcomes for the manager and the company (as well as the government). This part of the legislation therefore does not change the combined tax cost of providing deferred compensation under terms that reduce the manager's risk and that run counter to the long-term interests of the company and its shareholders. ${ }^{47}$

\footnotetext{
${ }^{45}$ Lucian Bebchuk and Jesse Fried, Pay without Performance, The Unfulfilled Promise of Executive Compensation 99-102 and 105-7 (2004).

${ }^{46}$ As argued above in part I.B, deferred compensation is inefficient for the company to the extent that the manager's choice of deferred compensation over current compensation results in the company funding the tax-benefit of deferral.

${ }^{47}$ This disregards any difference between the company's and the manager's tax rates.
} 


\section{B. The 20 Percent Surtax}

The considerations discussed in the previous section might lead one to conclude that effective deferred compensation reform requires imposing a significant tax penalty on bad deferred compensation to achieve the underlying tax and corporate-governance policy objectives. Possibly for this reason, the new legislation imposes a flat 20 percent surtax, payable by the manager and not deductible by the company, on any bad deferred compensation. Rather than advance the cause of reform, however, this approach probably does much more harm than good, particularly for the company's shareholders.

As a tax policy matter, a penalty structure such as the 20 percent surtax departs from the ideal of tax neutrality between current and deferred compensation by imposing a dispreference on the latter. Under prior law, the government suffers no revenue loss from deferred compensation - again, setting aside the question of differences between the manager's tax rate and the company's tax rate. Therefore, imposing a dispreference on certain forms of deferred compensation cannot be justified as an attempt to achieve the correct tax result (unless, which is plainly not the case here, that dispreference were calculated to correct for any difference between the manager's tax rate and the company's tax rate). ${ }^{48}$

As a corporate-governance matter, imposing a tax dispreference on the manager with respect to bad deferred compensation may actually harm the shareholders whom the dispreference is intended to protect. The determination of managers' pay in public companies appears to deviate substantially from the norm of arm's-length bargaining. ${ }^{49}$ Instead, many managers use their power and influence over the board of directors to extract rents from the company - constrained primarily by potential "outrage" costs if shareholders or third parties detect and protest the excessive pay. ${ }^{50}$ On this rent-extraction analysis, the processes for setting managers' compensation and the lack of adequate market constraints on those processes provide managers significant authority to determine the amount and type of their own compensation. ${ }^{51}$

Those fundamental corporate-governance problems have troublesome policy implications for any tax penalty on bad deferred compensation. The surtax under the new legislation attempts to curb bad deferred compensation arrangements by increasing the tax costs of those arrangements for the managers. However, the power of managers to extract rents from their companies implies that, wherever possible, managers will reallocate the risk of the dispreference to the companies. They might do so, for example, through tax gross-up or indemnification

\footnotetext{
${ }^{48}$ Arguably, such a sanction might have a marginal positive effect on the qualified plan system if it applied to all nonqualified deferred compensation rather than just to bad deferred compensation.

${ }^{49}$ See Bebchuk and Fried (2004). See also Lucian Arye Bebchuk, Jesse M. Fried, and David I. Walker, Managerial Power and Rent Extraction in the Design of Executive Compensation, 69 U. Chi. L. Rev. 751 (2002).

${ }^{50}$ Bebchuk, Fried, and Walker (2002).

${ }^{51}$ Ibid. For criticism of the analysis set out by Bebchuk, Fried, and Walker, see Kevin J. Murphy, Explaining Executive Compensation: Managerial Power versus the Perceived Cost of Stock Options, 69 U. Chi. L. Rev. 847 (2002).
} 
clauses in their contracts providing that, should the deferred compensation arrangement be determined to violate the new rules, the companies will pay additional compensation to make the managers whole (on an after-tax basis) for any resulting tax consequences. At best, that would leave the companies with an increased cost of providing deferred compensation to their managers because they would both fund the tax benefit of deferral and underwrite the risk of the tax penalty. At worst, reallocating the dispreference to the companies could leave managers indifferent between good deferred compensation and bad deferred compensation because, as with any insurance, the reduced risk-bearing might present moral hazard problems.

Whether any particular manager will successfully reallocate the cost of the surtax on bad deferred compensation to her company will depend, of course, on the level of power the manager has relative to the board. However, the widespread use of very substantial deferred compensation arrangements suggests that managers currently have the leverage to increase the value of their own pay at the expense of the company by choosing more costly deferred compensation over less costly current compensation. Against that background, one would expect that a manager would try to ensure that any penalty attributable to a bad deferred compensation plan would also fall on the company rather than the manager. That outcome would leave shareholders worse off than they were before Congress passed the new legislation.

The rent-extraction framework implies the inherent limitations of using tax policy to address issues of corporate governance. The tax law provides only the blunt policy instruments of preferences and dispreferences to regulate corporate governance, but the broad power of managers to extract rents suggests that they will use their power to capture most or all of the value of any preference and avoid most or all of the cost of any dispreference. In other words, a system of tax preferences and dispreferences to correct corporate-governance failures may work only if one assumes away the existence of those failures in the first place. Otherwise, the instruments of tax policy may simply exacerbate the consequences of the corporate-governance failures by increasing tax costs for shareholders. In fact, it is where the underlying corporategovernance failures are most serious that the attempt to correct them through tax policy will be most likely not simply to fail but actually to compound their adverse effects. That strongly implies that the 20 percent surtax in the new legislation represents terribly misguided policy.

\section{A Different Approach to Deferred Compensation Reform}

An important component of genuine deferred compensation reform is recognizing what can and cannot be accomplished within the limits of tax policy. The tax law does not create the agency problems that facilitate rent extraction by corporate managers; those problems reside in the relationships between managers and directors and between directors and shareholders. Any attempt to encourage or discourage specific compensation practices through the tax code must be assessed against the background of those relationships because the resulting tax incentives and tax penalties may have little of their intended effect once they become embedded in compensation contracts crafted to maximize managerial rents.

The better tax policy approach would be to avoid any preferences or dispreferences for specific forms of managerial compensation. Applied here, the appropriate tax policy objective would be to promote neutrality in the treatment of current and deferred compensation. The new legislation takes a half-step toward that goal by switching from substitute taxation of the company to accrual-based taxation of the manager in the case of bad deferred compensation 
arrangements. More by accident than design, this will partially eliminate the de facto tax preference that exists whenever the company's tax position permits it to avoid paying tax on investment earnings attributable to deferred compensation. Comprehensive reform would make the change for all deferred compensation arrangements, ensuring that investment earnings attributable to deferred amounts are taxed regardless of any difference in tax rates of the company and the manager. For arrangements that do not currently exploit any difference in tax rates, this approach would effect no change in the after-tax positions of the company and the manager (helping to minimize adjustment costs). ${ }^{52}$

Accrual-based taxation of the manager in all cases would raise two primary concerns: measurement of the amounts includible in the manager's gross income and the manager's ability to pay tax on amounts not yet received. At a minimum, both concerns would involve compliance and other costs for companies and managers. But those costs are probably not high enough to make accrual-based taxation unworkable. Measuring the includible amounts would be straightforward in the case of defined-contribution arrangements and would require making standardized assumptions in the case of defined-benefit arrangements. ${ }^{53}$ Although the need to make assumptions all but ensures overinclusions in some cases and underinclusions in others, this could be addressed through a "true-up" for the manager's inclusions and the company's deductions once the actual amounts are determinable. The need to make assumptions at the front end and corrections at the back end would be somewhat complex, but the compliance costs would fall on highly sophisticated taxpayers and likely would be only a very small fraction of the amounts deferred.

\footnotetext{
${ }^{52}$ The same tax-neutrality analysis implies the need for a critical review of existing dispreferences for other forms of managerial compensation - such as the rules for golden-parachute payments and the \$1 million cap on deductible compensation. These provisions operate primarily by increasing the after-tax cost to shareholders of certain forms of managerial pay. Again, they are grounded in the questionable assumption that the contract between the manager and the company is determined by arm's-length bargaining rather than through managerial rent-extraction. Both provisions probably would better serve their purpose if they were relocated from the tax code to the securities laws. The Sarbanes-Oxley Act of 2002 followed this approach with respect to loans from public companies to their managers and directors. Section 402(a) of Sarbanes-Oxley simply prohibits those loans under the securities laws, rather than attempting to regulate them through the tax code. For empirical studies questioning how much the $\$ 1$ million cap on deductible compensation has affected overall managerial pay, see Nancy L. Rose and Catherine Wolfman, Regulating Executive Pay: Using the Tax Code to Influence CEO Compensation, NBER Working Paper 7842 (Aug. 2002), and Brian J. Hall and Jeffrey B. Liebman, The Taxation of Executive Compensation, NBER Working Paper 7596 (Mar. 2000). Additionally, it is necessary to account for and assess tax rules that have collateral - and perhaps unintended - effects on corporate governance, such as the tax rules that frustrate managers' attempts to hedge risk associated with holding options on corporate stock but not the risk associated with holding corporate stock itself. See David M. Schizer, Executives and Hedging: The Fragile Legal Foundation of Incentive Compatibility, 100 Colum. L. Rev. 442, 474-94 (2000).

${ }^{53}$ For example, a deferred compensation arrangement that pays the manager at retirement an annuity of 2 percent of her final average pay multiplied by the number of her years of service and that includes a contingent early retirement subsidy would necessitate assumptions about the amount of the manager's final average pay and when she will retire (that is, how many years of service she will have and how old she will be). Of course, there would also have to be an assumption about the likelihood that she will live to retirement age.
} 
The liquidity issues presented by requiring managers to pay tax on amounts that they may not receive for many years in the future probably are less significant than they might appear. The law presents parallel results in the case of secured trusts ${ }^{54}$ and certain deferred compensation plans maintained by tax-exempt organizations or by state or local governments, ${ }^{55}$ so broader accrual-based taxation of deferred compensation would hardly be without precedent. Many managers covered by deferred compensation arrangements have substantial liquid assets (including base salary) to cover the tax that would be imposed on their deferred compensation. ${ }^{56}$ Additionally, it seems likely that the company would provide additional current compensation to the manager to meet any liquidity concerns. ${ }^{57}$

As Daniel Halperin has argued, imposing a separate tax, payable by the company, on investment earnings attributable to deferred compensation generally would achieve the same tax neutrality as accrual-based taxation of the manager. ${ }^{58}$ Although that approach avoids the liquidity problems of accrual-based taxation, it encounters similar (although not identical) problems of measuring the amounts deferred and the investment earnings on those amounts. More important, however, imposing a separate tax on the company would preserve the de facto tax preference found whenever the company is not subject to tax. One possible approach to implementing the type of tax on investment income advocated by Halperin without preserving the de facto tax preference would be to impose accrual taxation as the default rule with an exception for cases in which the company reports to the government and the manager that it has paid the separate tax on investment income. Under that approach, companies not subject to tax presumably would make no reporting, and the managers would pay tax under the accrual-based system. All other companies would pay the separate tax on investment income, and the managers would be relieved from accrual-based taxation. ${ }^{59}$

Beyond implementing tax neutrality through accrual-based taxation of managers, further regulation of deferred compensation would amount to regulation of the relationship between managers and companies rather than the relationship between managers and the taxing authority. Therefore, broader deferred compensation reform, focusing on corporate-governance and shareholder-protection issues, should be pursued outside the tax code. At a minimum, the securities laws could provide for better disclosure of the terms and costs of deferred

\footnotetext{
${ }^{54}$ Code $\S 402(b)$.

${ }^{55}$ Code $\S 457(f)$.

${ }^{56}$ One way to mitigate the liquidity issues would be to limit accrual-based taxation to managers above a certain income threshold; that would reduce the number of junior and mid-level managers who would have to pay tax on amounts that they may not receive for years into the future. For example, accrual-based taxation could apply only to managers whose annual pay (including deferrals) exceeds $\$ 1$ million.

${ }^{57}$ This would be particularly likely if accrual-based taxation were limited to managers whose annual pay exceeds \$1 million.

${ }^{58}$ See Halperin (1986), 539-50.

${ }^{59}$ The suggestion of using accrual-based taxation as a backstop for the separate tax on investment income, rather than as the primary operative rule, was made by Daniel Halperin in discussions with the author.
} 
compensation arrangements. ${ }^{60}$ For instance, shareholders could be better informed as to the aftertax economic costs to the company of allowing managers to defer their pay at a pre-tax rate of return. Enhanced disclosure could lay the groundwork for more aggressive shareholder protections, such as requiring specific shareholder ratification of the company's deferred compensation arrangements. ${ }^{61}$ Ultimately, however, the efficacy of deferred compensation reform will depend primarily on broader reform intended to minimize agency costs and rent extraction by managers. That broader reform falls well outside the limits of tax policy.

${ }^{60}$ This suggestion is also made by Bebchuk and Fried. See Lucian Arye Bebchuk and Jesse M. Fried, Stealth Compensation via Retirement Benefits 30-1 (Aug. 2004) (available at http://www.law.harvard.edu/programs/olin_center/ or at http://ssrn.com/abstract=583861).

${ }^{61}$ But see Bebchuk and Fried (2004), 198-99 (arguing that shareholder ratification cannot replace many board functions in setting managerial pay). 



\section{Other Publications by the Tax Policy Center}

\section{Discussion Paper Series}

\section{Number Title}

17

16

15

14

13 Searching for a Just Tax System

12 Tax Incentives for Health Insurance

11 State Fiscal Constraints and Higher Education Spending

10 Budget Blues: The Fiscal Outlook and Options for Reform

9 Private Pensions: Issues and Options

8 The Economic Effects of Long-Term Fiscal Discipline

$7 \quad$ Charitable Bequests and Taxes on Inheritances and Estates: Aggregate Evidence from across States and Time

6 The Enron Debacle: Lessons for Tax Policy

5 The Individual AMT: Problems and Potential Solutions

4 Providing Federal Assistance for Low-Income Families through the Tax System: A Primer

3 An Economic Evaluation of the Economic Growth and Tax Relief Reconciliation Act of 2001

2 How Marriage Penalties Change under the 2001 Tax Bill

1 The Effect of the 2001 Tax Cut on Low- and MiddleIncome Families and Children
Authors

Date

William G. Gale and Peter

R. Orszag

Leonard E. Burman, William G. Gale, Matthew

Hall, and Peter R. Orszag

William G. Gale and

Laurence J. Kotlikoff

Leonard E. Burman,

Richard W. Johnson, and

Deborah I. Kobes

Rudolph G. Penner

Leonard E. Burman, Cori E. Uccello, Laura L. Wheaton, and Deborah Kobes

Thomas J. Kane, Peter R. Orszag, and David L. Gunter

Alan J. Auerbach, William G. Gale, Peter R. Orszag, and Samara R. Potter

William G. Gale and Peter Orszag

William G. Gale and Peter Orszag

Jon Bakija, William G.

Gale, and Joel Slemrod

Jane G. Gravelle

Leonard E. Burman, William G. Gale, Jeffrey Rohaly, and Benjamin $\mathrm{H}$. Harris

Frank Sammartino, Eric Toder, and Elaine Maag

William G. Gale and Samara R. Potter

Adam Carasso and C. Eugene Steuerle

Leonard E. Burman, Elaine Maag, and Jeff Rohaly
December 2003

February 2003

October 2004

June 2004

July 2004

January 2004

May 2003

May 2003

May 2003

April 2003

April 2003

April 2003

September 2002

July 2002

March 2002

May 2002

April 2002 


\section{Issues and Options Series}

\section{Number Title}

$7 \quad$ Promoting 401(k) Security

6 Effects of Estate Tax Reform on Charitable Giving

5 The AMT: Out of Control

4 Saying "I Do" after the 2001 Tax Cuts

3 EGTRRA: Which Provisions Spell the Most Relief?

2 The Estate Tax Is Down, But Not Out

1 Designing Tax Cuts to Benefit Low-Income Families
Author

J. Mark Iwry

Jon M. Bakija and William G. Gale

Leonard E. Burman, William G. Gale, Jeffrey Rohaly, and Benjamin $\mathrm{H}$. Harris

Adam Carasso and C. Eugene Steuerle

Leonard E. Burman, Elaine Maag, and Jeff Rohaly

Leonard E. Burman and William G. Gale

Frank Sammartino

\section{Date}

September 2003

July 2003

September 2002

August 2002

June 2002

December 2001

June 2001 